1995;122:658-663.

11. Stroud LA, Tokars JI, Grieco MH, et al. Evaluation of infection control measures in preventing the nosocomial transmission of multidrug-resistant Mycobacterium tuberculosis in a New York City hospital. Infect Control Hosp Epidemiol 1995;16:141-147.

12. Maloney SA, Pearson ML, Gordon MT, et al. Efficacy of control measures in preventing nosocomial transmission of multidrugresistant tuberculosis to patients and health care workers. Ann Intern Med 1995;122:90-95.

13. Fraser VJ, Johnson K, Primack J, Jones M, Medoff G, Dunagan WC. Evaluation of rooms with negative-pressure ventilation used for respiratory isolation in seven Midwestern hospitals. Infect Control Hosp Epidemiol 1993;14:623-628.

14. Lifson AR, Watters JK, Thompson S, Crane CM, Wise F. Discrepancies in tuberculin skin-test results with two commercial products in a population of intravenous drug users.J Infect Dis 1993;168:1048-1051.

15. Rupp ME, Schultz AW Jr, Davis JC. Discordance between tuberculin skin-test results with two commercial purified protein derivative preparations. J Infect Dis 1994;169:1174-1175. Letter.

16. Ramirez JA, Anderson P, Herp S, Raff MJ. Increased rate of tuberculin skin-test conversion among workers at a university hospital. Infect Control Hosp Epidemiol 1992;13:579-581.

17. Adal KA, Anglim AM, Palumbo CL, Titus MG, Coyner BJ, Farr $\mathrm{BM}$. The use of high-efficiency particulate air-filter respirators to protect hospital workers from tuberculosis. A cost-effectiveness analysis. $N$ Engl J Med 1994;331:169-173.

18. Fridkin SK, Manangan L, Bolyard E, Jarvis WR. SHEA-CDC TB survey, part I: status of TB infection control programs at member hospitals, 1989-1992. Infect Control Hosp Epidemiol 1995;16:129-134.

19. McDiarmid M, Gamponia MJ, Ryan MAK, Hirshon JM, Gillen NA, Cox M. Tuberculosis in the workplace: OSHA's compliance experience. Infect Control Hosp Epidemiol 1996;17:159-164.

20. Fridkin SK, Manangan L, Bolyard E, Jarvis WR. SHEA-CDC TB survey, part II: efficacy of TB infection control programs at member hospitals, 1992. Infect Control Hosp Epidemiol 1995;16:135-140.

21. Bailey TC, Fraser VJ, Spitznagel EL, Dunagan WC. Risk factors for a positive tuberculin skin test among employees of an urban, Midwestern teaching hospital. Ann Intern Med 1995;122:580-585.

\title{
Hepatitis B Outbreak in EEG Clinics in Toronto
}

Gina Pugliese, RN, MS Martin S. Favero, PhD

At the recent meeting of the American Society for Microbiology in Miami Beach, Florida, M. Fearon and coinvestigators described one of the largest reported outbreaks of hepatitis B virus infection linked to a healthcare facility, involving 75 patients. In January 1996, the investigation of several cases of hepatitis B cases in Toronto, Ontario, Canada, led to the identification of having an electroencephalogram (EEG) at one of several EEG clinics as a common link. Although recommendations were issued in 1991 for the use of disc electrodes, several clinics continued to use intradermal (needle) electrodes until January 1996. All the clinics were under the direction of the same physician with one technician performing all of the EEGs.

An investigation was conducted in March 1996, and all 18,567 patients who had attended these clinics between 1990 and 1996 were contacted by mail and offered testing for hepatitis B. Of the 18,567 patients contacted, 7,942 were tested for hepatitis B surface antigen ( $\mathrm{HBsAg}$ ), surface antibody (anti-HBs), and core antibody (anti-HBc) and, if needed, hepatitis $\mathrm{B}$ e-antigen, anti$\mathrm{HBe}$, and anti-core IgM. A total of 75 patients met the case definition for the outbreak; 71 were $\mathrm{HBsAg}$ positive. All cases occurred on different days, and not all had attended the same clinic.

Subtyping and viral sequencing was done on 25 of the 71 cases that were found to be HBsAg positive. The subtying and sequencing did not support patient-to-patient transmission. However, a group of six patients had virus identical to that of the clinic technician (who was both HBsAg and $\mathrm{HBeAg}$ positive). This virus (subtype ayw2) was distinctly different from the chronic carriers or any of the community controls. Investigations at the clinics revealed that infection control measures did not meet existing standards for needle electrode handling and sterilization and the use of gloves during these procedures. Patients also reported bleeding of the scalp after electrode insertion.

The investigators point out that this outbreak has implications for the current recommendations of HBeAg-positive healthcare workers and invasive procedures and conclude with stressing the importance of hepatitis B vaccination of all healthcare workers.

FROM: Fearon M, Johnson I, Nicholas K, et al. An outbreak of hepatitis B associated with EEG clinics in Toronto. American Society of Microbiology Annual Meeting; Miami Beach, Florida; May 1997. Abstract C162. 